\title{
Retracted: Stable Plastid Transformation for High-Level Recombinant Protein Expression: Promises and Challenges
}

\author{
BioMed Research International \\ Received 4 May 2014; Accepted 4 May 2014; Published 8 May 2014 \\ Copyright (C 2014 BioMed Research International. This is an open access article distributed under the Creative Commons \\ Attribution License, which permits unrestricted use, distribution, and reproduction in any medium, provided the original work is \\ properly cited.
}

This paper [1] has been retracted as it is found to contain a substantial amount of material from the paper "Chlamydomonas Reinhardtii Chloroplasts as Protein Factories" by Stephen P. Mayfield, Andrea L. Manuell, Stephen Chen, Joann Wu, Miller Tran, David Siefker, Machiko Muto, and Julia Marin-Navarro published in Current Opinion in Biotechnology in April 2007.

\section{References}

[1] M. Gao, Y. Li, X. Xue, X. Wang, and J. Long, "Stable plastid transformation for high-level recombinant protein expression: promises and challenges," Journal of Biomedicine and Biotechnology, vol. 2012, Article ID 158232, 16 pages, 2012. 